\title{
Plato: Moral Priest of Athens
}

Karan (Sunny) Khanna

Second Year Paper

Citation Style: APA

There are few men in history who have more perturbed the minds of mankind than Plato; fewer still have had more influence on the thinkers and philosophers, idealists and realists, musicians and amateurs. His works deal with all such themes, they try to discern the nature of soul and the beauty of the cosmos, the meaning of justice and the reason to be good. Plato towered above his age as Voltaire had done in the eighteenth century, Tolstoy in the nineteenth, and Russell in the twentieth. His masterpiece, The Republic, is considered to be one of the greatest pieces of literature and philosophy ever composed. On the whole, this paper would agree with the statement that Plato $^{1}$ was more of a social critic and The Republic is a fiercely moral book, which conveys a pitiless assessment of democracy. It will, however, contend that he did not set out to create a utopian society; instead, it will conclude with an argument that his ideas paved a way for a sort of kallipolis where few, if any, would like to live.

To comprehend the true nature of Plato's work, it is vital not to be inveigled by the unforgettable purple passages he has weaved, caparisoned with poetic words. The Republic is written in a form of Socratic dialogue, in which the ever-sagacious Socrates and the sybaritic young aristocrats of Athens discuss myriad of issues of life and death; and it all beings with the nature of Justice. Plato, the moralist, believes a man must be "just," for the city is an ethos of human soul (Plato 1991). Plato's Socrates indulges the views of three aristocrats on this subject: Cephalus is of the opinion that speaking the truth and paying one's debts is a correct definition of justice (Plato 1991, 8-9). Polemarchus believes that to give friends what is good and evil to enemy is a true meaning of justice; furthermore, it is also useful in contracts, so as to lending or depositing certain items (Plato 1991, 10). Lastly, the cynic Thrasymachus vituperates that "Justice is the interest of the stronger or ruler" and all forms of government make laws to serve their own interests (Plato 1991, 19-20).

Plato's Socrates listens patiently but one-by-one repudiates the arguments of all three men. Cephalus' idea of Justice cannot be its complete definition because one will not return a

\footnotetext{
${ }^{1}$ Historians and scholars are divided whether the views presented in The Republic are those of Plato or Socrates. Since this paper related to the author of the work, I will use "Plato" or "Plato's Socrates."
} 
mentally deranged person their weapons, any more than they "would say that I ought to speak the truth to one who is in his condition" (Plato 1991, 9). Polemarchus' view is also refuted with same method and ingenuity when Socrates inquires of him whether "practising the art of theft" for our friends can be of any good? (Plato 1991, 16). To the vituperation of Thrasymachus, Socrates' answer is simple: a ruler will rule in the interest of the people, just like a true artist is not concerned about himself, but about his subject (Plato 1991, 26-31). Upon refusing to provide a definition of justice when he is called upon to do so, he can only claim that he does not know; but justice and happiness are inextricably connected (Plato 1991, 41). This is the first and last time when Plato truly philosophizes in the entire work, for it is the only time when we see the moral relativism of Plato. As the founding of kallipolis proceeds, Plato will be metamorphosed into moral absolutist and create ideas more frightening for the "good of the city."

In the second book of The Republic, we begin to see the subtle elimination of philosophy, when reason is replaced by certain elements of fascism. None coruscates more clearly than when Plato's Socrates discusses the education of the young with Glaucon and Adeimantus. Socrates suggests establishing the censorship "of the writers of fiction, and let the censors receive any tale that is good, and reject any that is bad; and we will desire mothers and nurses to tell their children the authorised ones only" (Plato 1991, 72). Plato's incessant need to supress what he considers "immoral" emerges again and again throughout the book.

Yet he contradicts himself as he writes in the third book, "truth should be highly valued" - that truth should suit the needs of the rulers of the city (Plato 1991, 86). His dogmatic morality asks the rulers to purify the image of gods, where he also accuses Achilles of "downright impiety" (Plato 1991, 89). By the end of The Republic, it seems Plato is torn apart between the emotional part of the soul and the rational one. As he writes, "we are ready to acknowledge that Homer is the greatest of poets... but we must remain firm in our conviction..." that his irreligious works must be extinguished, and the youth must only be told the harmonizing hymns and praises to the gods (Plato 1991, 378). Unlike his pupil, Aristotle, it seems Plato was a fanatic priest of rationale, and led him to preach ideas more dangerous than the banishment of certain works or the expulsion of certain people.

A great German writer, Heinrich Heine, once wrote: "Where they have burned books, they will end in burning human beings." This is a precise route where the banishment of 
certain works leads to in Plato's Utopia. In the fifth book, he invariably creates a plan which will be an inspiration of more heinous forces, more than two millennia later than when he wrote his masterpiece - a plan for eugenics. Plato, the social critic, is concerned with the arrangement for enhancing the breeding of men and women in any society, despite its political arrangements. As he tells Glaucon, "the best of either sex should be united with the best as often, and the inferior with the inferior, as seldom as possible; and that they should rear the offspring of the one sort of union, but not of the other, if the flock is to be maintained in the first rate condition" (Plato 1991, 181-182) This macabre sketch, however, becomes more ominous as he requests that "these goings on" must remain furtive, and known to the rulers only (Plato 1991, 182). Again, it seems that Plato's morality hinders him to acknowledge the individuality of human soul; for him the soul of man is the very essence of the kallipolis, and he is prepared to abrogate the laws of nature to achieve his Utopia.

Though for the most part, The Republic is work of dogma beneath a tantalizing veil of drama, one cannot but admit that Plato was one of the first philosophers - in both the Occidental and Oriental worlds - whose precocity suggested that women be equal to men (Plato 1991, 174). He proudly proclaims to Glaucon that when certain legal laws or conventions which do not give women same rights and responsibilities as men, the "violation of nature” supervenes (Plato 1991, 177). Plato's reason behind this is unexpectedly modest: both sexes have their respective abilities, thus for the prosperity of the city, both sexes must contribute what they have to offer (Plato 1991, 176). In doing so, they will truly nourish the soul of the city.

Plato's entire book swims in the sublime pool of contradictions, but nowhere has the inconsistencies been more intense or clear than his most famous thought: the Allegory of the Cave. This allegory has been seen as one of the most remarkable defenses of enlightenment and enquiry ever devised in the history of human race. In the seventh book, Plato's Socrates asks Glaucon to imagine human beings living a dim cave, and can only see the shadows. For years this would their reality, but then what happens when someone breaks the shackles, drags himself upwards and is dumbfounded by the light. Gradually and deliberately, however, he will be used to the brightness of the light and would see the authentic world as it is, not as what he thought (Plato 1991, 253-257). He ends his metaphor with a message that has haunted the philosopher and thinkers ever since, “...My opinion is that in the world of knowledge the idea of good appears last of all, and is seen only with an effort" (Plato 1991, 257). 
Men throughout generations have pertinently thought of this immortal parable as Plato's insistence that the discussion about what is good, beautiful, noble, sublime, just, and pure will never end; before we can find answers to these questions we must liberate ourselves from the hideous manacles of doctrines and dogmas. This, however, contradicts everything and threatens the very moral fibre of his kallipolis. He tells Glaucon that men must be free from their dark caves and see the light, but then, as mentioned above, he also would want the youth not to know certain Homeric hymns and banning of "immoral" art, music and literature that does not suit the needs of the rulers. In demanding such censorship, he would hinder people from seeing and expiring the ever brightening, shining gleam of enlightenment.

The Republic is a book less about politics, and more about morals. Here and there we see little phosphorescent gleams of enlightenment, like irresolution on nature of justice and the rights for women, but on the whole, Plato composed a symphony to establish law and order; my view is that humanity, truly enlightened humanity, would rather prefer the rhythm of chaos.

Whether he created this work to warn us about totalitarianism, or he truly believed in it, we will never know. It is, nonetheless, undeniable that this book lays down the framework for dictators - some of them were benevolent, but most depraved. Perhaps I, an Aristotelian, am being unfair to Plato. For the irrefutable, irrevocable steps of history can neither be stilled nor stopped. So before we bestow the verdict of "guilty" to Plato, we must recognize that through his works he could pierce through ideas which seem impenetrable, and give us something to think about, talk about, and to crave more of: an ecstasy of philosophy. 


\section{Works Cited}

Plato. The Republic. New York: Random House, 1991. 